books of other writers, interweaving with these a multitude of glosses for ecclesiastical, medical, and logical terms, adding the names of their authors, as well as expressions of various dialects, of which they were aware, as he himself professes in his preface. From these sources, many glosses, which Bar Bahlul had omitted, were very likely interpolated, given that these are lacking in certain manuscripts. Very likely there is but little interest to know whether these glosses were introduced by Bar Bahlul himself, or by another compiler, and (furthermore) the one who would attempt it would work in vain. Thus it is most expedient to choose the manuscripts (containing) the best versions of the lexicon, and subsequently to note the varying readings of the other manuscripts at the bottoms of the pages. Lagarde himself recommended this approach, writing: ${ }^{30}$ "Those (works) that we name 'Bar 'Ali' and 'Bar Bahlul' are collections of glossaries of unequal value and diverse authorship (produced) over several centuries." He ultimately prescribed the edition of an "integrated corpus of glosses." You should know that the oldest manuscript of the lexicon which has come down to us was written long after the death of Bar Bahlul and contains a great deal of interpolation in the text. You may see also an article in a journal where at one point we discussed this question: Journal Asiatique, January-February I894, I42 and subsequent.

The manuscripts of Bar Bahlul's lexicon are described below. The method I have used in editing is described in the preface to the first fascicule. A new 'Jacobite' manuscript (under the sign $\mathrm{P}$ ) is to be added (to that account), which is kept in the national library in Paris. It came to us from the Orient while the letter $p \bar{e}$ of our edition was in press. Various readings which it offers may be seen from column 1535 (see note 4 beneath that column). It differs a little from the Socinian manuscripts, and contains many additions.

\title{
III. ON THE SOURCES OF THE LEXICON
}

Bar Bahlul excerpted the glosses of his lexicon from many books, mentioning both the titles of works and the names of authors. Whatever we know of these we give (here), following the order of the alphabet: ${ }^{31}$

Abba of Kaškar. He became patriarch of the 'Nestorians' in the year 741, 1063:24, , s

\footnotetext{
$3^{30}$ Gesammelte Abhandlungen, 3.

${ }^{31}$ Translator's note: These entries are given following the order in which Duval arranged them, and thus do not follow strictly the order of the alphabet in translation.
} 


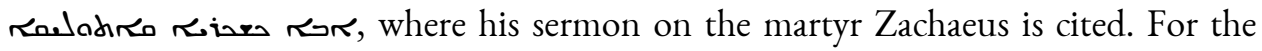
works of Abba II see Assemani, B. O., III, part I, I54.

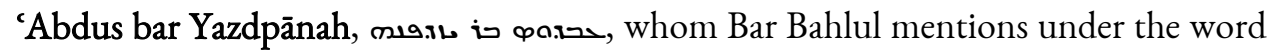
I78:22, Rival r. The note $\overline{\text { L }}$ (227:I) seems very likely to be an indication of this name. It is doubtful whether this author is the same as 'Abdus, the physician of the caliph Mu'tadid, who wrote a book of medical memorabilia (تذكرة في الطب) (cf. Ibn Abī Usaybi'a, I, 23I).

Abū Ya'qūb ibn 'Abdān. In the lexicon this name is cited three times: 487:2, under

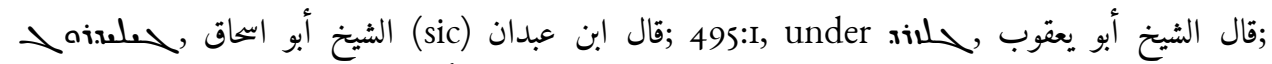
944:ult, under وقال أبو يعقوب لهمبر. Among the Arabs the name Isḥāq and the cognomen Abū Ya'qūb are not rare, but whether these were Ibn 'Abdān, a contemporary of Bar Bahlul's, we do not know.

Abū al-Hasan 'Alī ibn Yáqūub wa-akh Ișțafān, who is styled the patriarch of Antioch. He had asked Bar Bahlul about the term $\delta ı \alpha ́ \psi \alpha \lambda \mu \alpha$, to whose response written by letter he refers, 557:I5: سألت عن تفسيره أبا الحسن علي ابن يعقوب أخا اصطفان وقد صار بطرك انطاكية بعد أحلاند. Abū Zayd. His interpretation of the word dacex in the Pešițtā (Dan., I, I3) is cited, أبو زيد حنين I970:Ir. It is doubtful whether this refers to Hunayn, whose full name was •ابن إسحق العبادي.

Abzud the Scholar, rescor sas, who is also (called) Bazud and Michael. He was the author of the Book of Definitions. Bar Bahlul, in his gloss to the word rhi, I843:8, excerpted from this book, which is contained in manuscript 88, folio I9Ib in the Royal Library of Berlin (cf. Sachau, Verzeichness der syr. Handschr. zu Berlin,

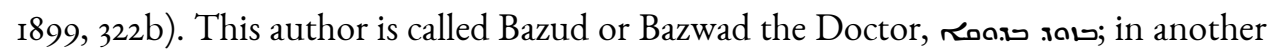
manuscript (India Office), kept in London, the Book of Definitions is attributed to Michael, cf. Hoffmann, De Hermeneuticis apud Syros Aristoteleis, I5I, and Opuscula Nestoriana, xxi. Abzud seems to have lived around the year 900.

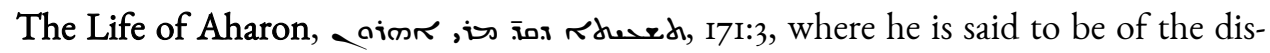
trict Alon in the province of Melitene. For the life of this holy monk, see Bar Hebraeus, Chronicon Ecclesiasticum, I, 87; Wright, Catal., II24, no. 7.

Aqulas (Aquilas? Ocellus?), 1785:20, , אבר אم lary. For this alchemist see Berthelot, La chimie au moyen âge, II, xxxv, not. I, and in the index under the entry Acolos, Aquila, Akoulas.

Al-Manșūrī, see al-Rāzī. 


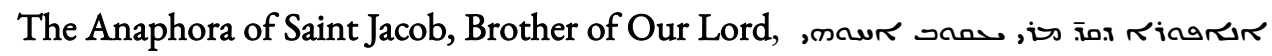
I650:7, isi, under the word ring.

Books of Antidotes. Books of this genre are cited in Bar Bahlul's lexicon under the

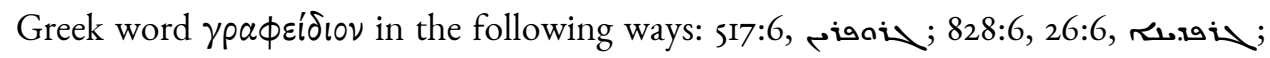

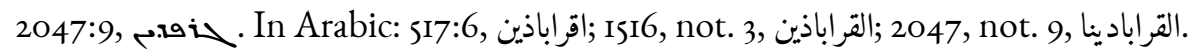

Fables of the Aramaeans, 896:12; I037:3; IO5I:I9; II48:2; II53:24; 1352:24; 1356:16; I369:I5; 1979:10; 2007:2; $2072: 18$. In these places it is our belief that the book of the fables of the Aramaeans of Bet

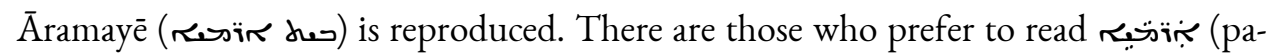
gan) for متنتخي (Aramaean), and understand (these to be) the fables of the pagans, i.e. the Harrānenes, cf. G. Hoffmann in Z. D. M. G., XXXII, 756. It is true that in a gloss

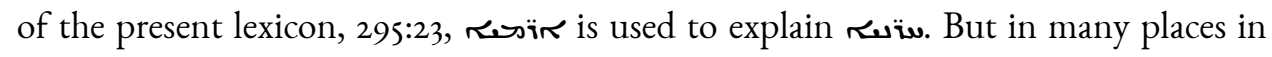
the lexicon, words of the Harrānene usage are referred to and cited under the name

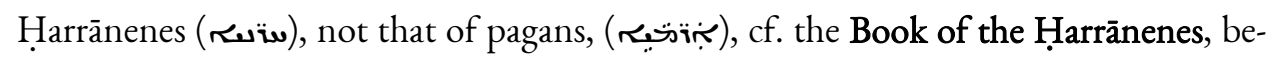

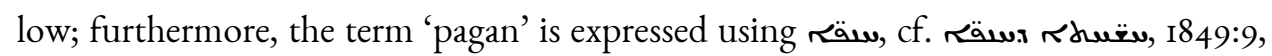
and again, the word risoos, I037:3, which seems to have been borrowed by the Syrians of Babylon from the Persian language. Gloss 1226:7 is not an obstacle, אתre, which signifies that the given word occurs in both books, to wit, in the fables (of the Aramaeans) and in the Book of the Harrānenes. Immanuel Loew demonstrated, in Z.D.M.G. XXXI, 535 and subsequent, that these fables are foreign to the book of Kalila and Dimna.

'Awān (?), a doctor in the 'Nestorian' monastery of Mar Gabriel, near Mosul, w w ד

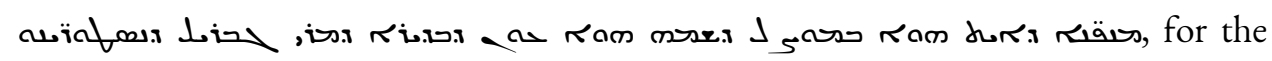
word حلم, Ecclesiastes, VI, 6.

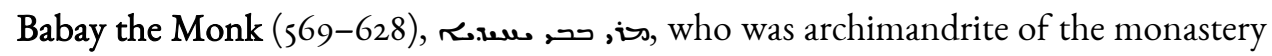
of mount Izla, wrote many books. Bar Bahlul mentions him, along with Zachariah of Merv, under the word raم, 5 , 1675:9.

Bar Daqnānā, حi s a syriac author of whom little is known, cf. Assemani, B. O., III, part I, 232, note 2 (where the reading Ecchellensis is to be preferred). Bar Bahlul cites some verses from his metrical homilies, which seem to be devoted to wine and romance: II89:3, and II93:3 (each of these two verses are seven-syllable verses ending

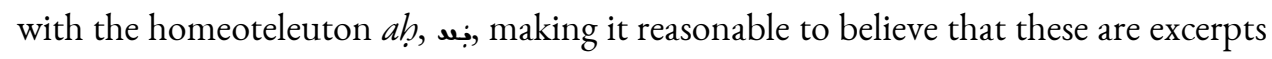
from homilies); 1975:4 (one verse containing I2 syllables). From the homeoteleuton and the writing on the art of love, you may say that the author was not much older 
than Bar Bahlul and lived in the 9th century. Single words occurring in other glosses may have been taken from this source: I02:12; 380:9; 811:7; 953:17; 1266:4; 1340:pen.; I407:I; I468:I4; I674:I4, I680:7; I937:I.

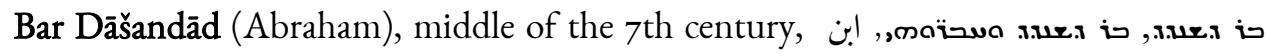
داشنداد وأصحابه. Abraham the son of Dāšandād taught at the school of Babay bar Nesibnāye established at Bašuš; his associates, أصحابه, vحتمهm, seems to refer to the instructors of this school. In his preface Bar Bahlul mentions Bar Dāšandād expressly. He wrote in Syriac, and the glosses cited in the lexicon refer to Syriac words: I45:I; I6I:6; I215:22; I367:I; I390:I8; I784:20; 2052:9. 'Abdišo' mentions the work of Bar Dāšandād in his catalogue; see Assemani, B. O., III, part I, 194.

Bar Hatim, כi w wod, ابن حاتم, يجيى ابن حاتم. Under this name a few Greek and Syriac

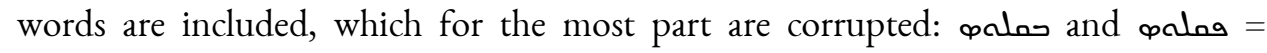

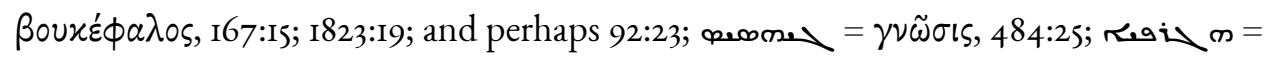

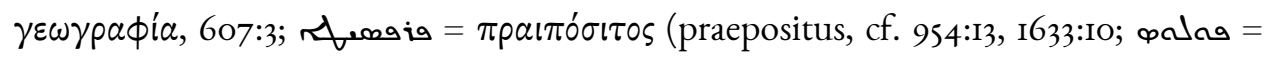

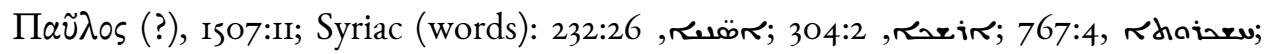

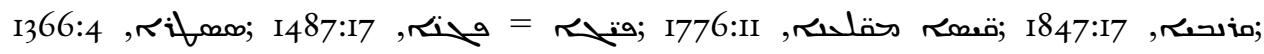

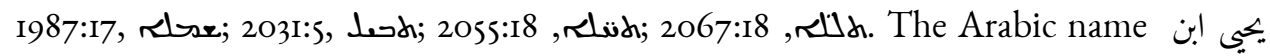
حاتم is written fully, 1366:4. Who this Syrian was, we do not know; it is neither Ahmad ibn Ḥātim, أحمد بن حاتم, nor Abū Ḥātim al-Sijistānī, أبو حابم السجستاني.

The Longer Grammar of Bar Hebraeus, which the author called the Book of Splen-

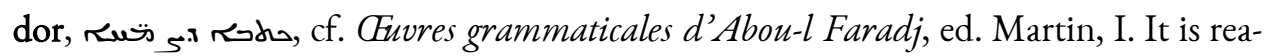
sonable (to assume that) a 'Jacobite' interpolator was responsible for adding a certain number of glosses from this grammar, which was written several centuries after Bar Bahlul's death, to the lexicon; Bar Hebraeus himself died in the year I286. These glosses relate to the art of grammar, I5O:21, etc.

Bar Sawma of Tahal, redud ras 5 ira, 167:22; he may be the same as Bar Șawma, bishop of the city of Nisibis, who was expelled from Edessa after the death of Ibas ( $\uparrow$ 457) with the other 'Nestorians'.

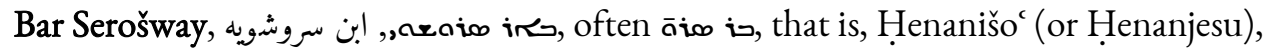
the son of Serošway, bishop of the city of Hirta, who flourished at the beginning of the 9 th century. His Syriac lexicon, for which see above, is cited on many pages of Bar Bahlul's lexicon. It seems that his name was inserted many times through scribal error:

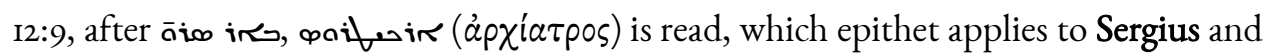
not to Bar Serošway, cf. ibidem, not. 23; in other places $(52: 22,64: 8)$ the epithet sials 
(doctor) occurs, (which is) equally false.

Basil the Great. (Fragments) from his nine sermons on the creation of the world are extant in two places in the lexicon; one, on the halcyon, is given next to a gloss of Bar Serošway's, I80:9; the other, on crystals, 1836:ult. Cf. below Physiologus, and Land, Scholia in Physiologum Leidensem in Anecdota syriaca, IV, I33. Basil is cited in other

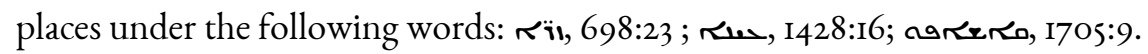

Benjamin the Monk, ح.u. his commentary on the writings of Dionysius the Areopagite is cited. A note added to the London manuscript, Add. I2152, which contains the works of Dionysius the Areopagite, reads, "At the time that these works were transcribed (the year 837), in the great monastery of Teleda, situated in the province of Antioch, our master in dogmatics Mar Benjamin lived tranquilly"; see Wright, Catal., 498. This description seems appropriate for our Benjamin the Monk, who was a monk of Teleda and of the Monophysite sect. It is true that translations and commentaries on the works of Dionysius the Areopagite were composed by Syrian Monophysites, but nothing indicates that the glosses of Benjamin in the lexicon of Bar Bahlul the 'Nestorian' were inserted by an interpolator.

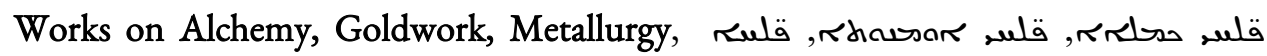
أصحاب الكيميا ;حمoshich words in the lexicon have this meaning; see entries in

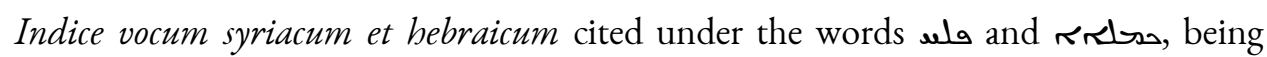

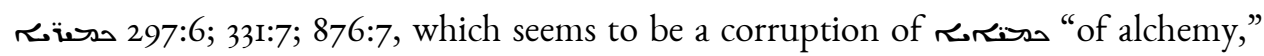

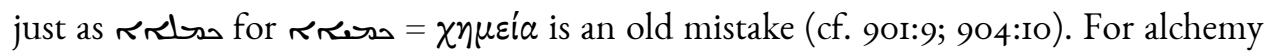
among the Syrians see Berthelot, La Chemie aux moyen âge, vol. II, where many of Bar Bahlul's glosses on metals and stars are found.

Chronograph, , 75:12

Arabic Commentary on the Psalms, whose author is not mentioned, مفسّر الداود, 85:II; المفسّر اللداود, 1999:14.

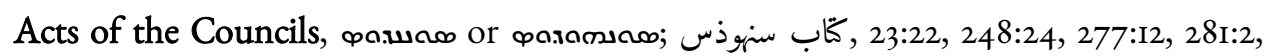
1771:I5, cf. 264:I7, on the patriarch Ephesinus ordered arrested by the council of Nicaea.

Constantine, قسطنطين, قوسطنطين. A few glosses inserted into Bar Bahlul's lexicon under this name seem to come from an Arabic commentary on the Pentateuch following the Pešițtā version, 532:3, 592:3, 732:7, 870:3, 1365:5, I632:15. 
Cyriacus, אم: II2I:23, on the word rhas; this may be Cyriacus, bishop of the city of Nisibis (around the year 630), for whose works see Assemani, B. O., III, part I, 2I5.

Cyril, cited for the word 500:20. This Cyril is indeed the Alexandrian, whose gloss on Matthew XXIX, 24 it is reasonable to believe was excerpted from his commentary on the New Testament. It appears that this gloss is not found in the 'Nestorian' manuscripts, and was inserted into the lexicon by a 'Jacobite' interpolator. Thus Gesenius' note is not correct, who wrote on Cyril in discussing the rich manuscripts of Bar 'Ali: "This is Cyril of Jerusalem, rather than the Alexandrian so hated by the 'Nestorians"”; Sacra Pentecostalia, 24.

Daniel of Garam, Bishop of Tahal, whom Bar Bahlul mentions among the writers cited in his lexicon in his Syriac preface, but whose name occurs nowhere in the lexicon. This is Daniel bar T Tubanita, bishop of Tahal, who composed many Syriac works, and who refuted the doctrine of Isaac of Nineveh. The era in which he lived is uncertain; it may be that he was a contemporary of Isaac's in the seventh century, cf. Chabot, Notes sur la littérature syriaque, in Revue sémitique, 1896, 254 and 257.

Dioscorides at times is cited from the Arabic compendium of Gabriel ibn Bokhtišo', and at times from Hunayn's Syriac version; see Gabriel and Hunayn, below.

The Homilies of Domitian, $\downarrow$, of the martyr Domitian; see Wright, Catal., II49, Add., I720I. The life of this saint has been edited by Bedjan in Acta mart. et sanctorum, VI, 536 and subsequent.

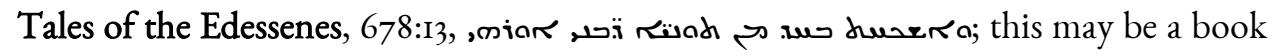
of entertaining stories composed in popular dialect; compare, 1755:4; rmiono ridir nel, 2077:6.

Elias of Anbar, iصrex, 803:pen, on the name, Marc., x, 46. This Elias flourished around the year 922; he composed three volumes of verse, an apology, letters, and sermons. See Assemani, B. O., III, part I, 258.

Elias the Bishop of Jerusalem, who is said to be 'Ali the son of 'Ubayd, اليّا أسقف المقدّس المعروف بعلي" بن عبيد. The lexicon of Bar Bahlul contains Arabic glosses of Syriac words under his name, 286:12, 583:19, 620:3, 659:13, 1263:8, 1313:22, I488:I, 1710:pen., 1942:5, 2068:8. He may be the same as Elias al-Jawharī, who was bishop of Jerusalem, and who was made metropolitan of Damascus after the year 893. Elias al-Jawharī translated the collection of 'Nestorian' councils from Syriac into the Arabic language and composed a book on a proposed unification of the Christian sects; see Assemani, B. O., III, I, 5I3; 
II, 220; Guidi in Z. D. M. G., XLIII, 388.

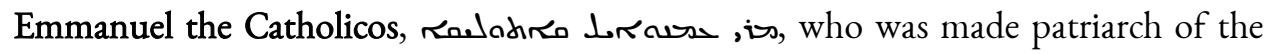
'Nestorians' in the year 937 ( $\$$ 960), cf. Bar Hebraeus, Chron. eccl., II, 245. Cited under the word renc, 1930:6.

'Enānišo' the Monk, r.ue century. He composed a book on the rules of grammar, from which Bar Bahlul's gloss on the word rradud seems to be an excerpt; for this book see G. Hoffmann, Opuscula nestoriana; R. Gottheil, A treatise on Syriac grammar by Mar Elias of Sobha.

Ephrem the Syrian (\$373), 712:22, I709:I8, 1732:21, 1769:6, I774:9, I929:Ir. His Testamentum is cited, 712:22, 1774:9; his hymn and praise of Abraham Qidunaya, 1769:6.

Canon of the Epiphany, مسח 377,23, 791:22; from the book of the Syriac liturgy.

Epiphanius, on Job, II6:8.

On the Pagan Festivals, I423:19, حصi ; this may be the book of the liturgy of the Harrānenes, see Book of the Harrānenes, below.

On Etymology, which treats the derivations of words, I5:II, 36:23, 57:4, 58:8, 194:13, 196:6, 224:ult, 225:16, 264:23, 399:19, 655:6, 794:8, 799:13, 820:IO, II48:I, II51:8, I316:25, I850:17, I886:17, I928:18, I934:5, I941:20, 1966:19, 1971:8. The book that Bar Bahlul cites under this name seems to have been a compendium of derivations and difficulties of words, to which Payne Smith draws attention in his Thesaurus syr., I54I.

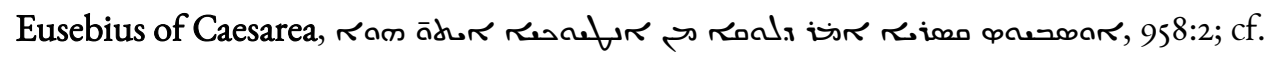
Eusebius' Historiam eccl., III, iv, 6.

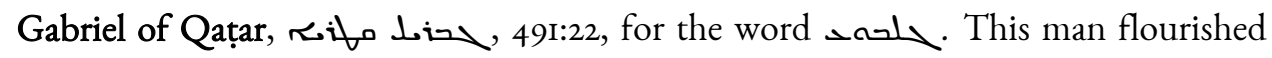
around the year 740 and composed a book on faith and unification; see Assemani, $B$. O., III, i, I72.

Gabriel ibn Bokhtišo' (Bokhtjesu), جبريل, sometimes in the manuscripts جبرايل, son of the celebrated physician George Bokhtišo' and himself a physician in Baghdad, in the ninth century, under the rule of the caliphs Hārūn al-Rashīd, Amīn, and Ma'mūn. He composed a compendium (كاش) of the works of Dioscorides, Galen, and Paul of Aegina in Arabic, from which the names of plants and materia medica are very often cit- 
ed in Bar Bahlul's lexicon, in the following ways: وأمّا جبريل ابن بخت يشوع فيكى عن جالينوس حكى جبريل عن

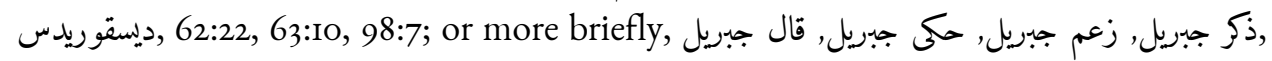
I8:3, 29:IO, 32:2, 55:I, 63:16 and 2I, 68:16, 69:22 and pen., 7I:2, 83:pen., 84:6 and 23, 89:19, 93:23, 94:27, etc. Gabriel did not himself make use of Greek sources, not going beyond the use of Syriac and Arabic translations; see herein Galen, Dioscorides, Paul of Aegina. "This Arabic compendium," according to Immanuel Loew (Aramaeisch Pflanzennamen, I2 and I3), "contains no Syriac words, yet on the other hand generated an abundance of errors. During the translation into Arabic of Greek words using the Syriac script, the Greek names of plants were corrupted in a shocking way, and Bar Bahlul did not omit the occasion to carry over this corrupt vocabulary as new words at the heads of entries or as synonyms in the midst of entries." For the false attribution of a lexicon to Gabriel, see above, viii.

Galen is cited from the Syriac translations of Sergius and Hunayn and from the Arabic compendium of Gabriel; see Sergius, Hunayn, Gabriel. At times Bar Bahlul gives Syriac and Arabic glosses of Galen without indicating the translator: 84:26, 819:9, 864:7, I5I6:4, 2000:I2.

Syriac Geoponica. Bar Bahlul excerpted a few names of plants and animals from an

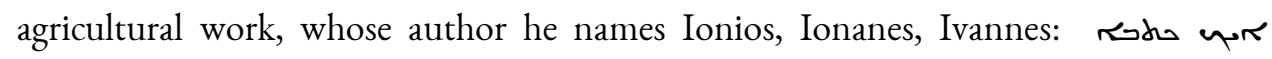

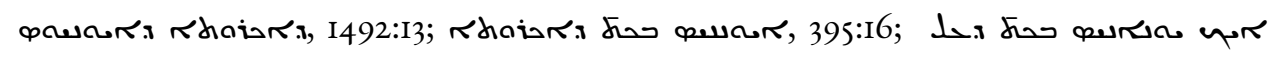

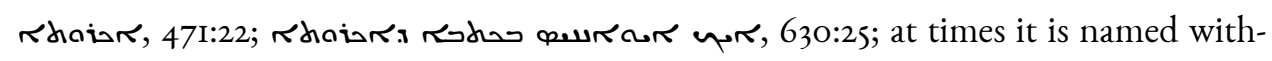

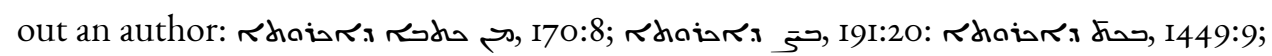
I7OI:I5. It is now an established fact that the form Ionos is to be preferred, which is

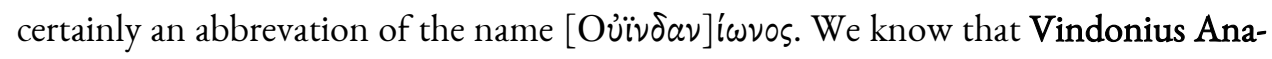
tolius (or Vindanus) wrote a work on agriculture in Greek, which was entirely included in Cassiani Bassi's now-lost Greek compilation. It seems that the Syriac version of Vindonius' Geoponica by Sergius of Reš 'Aynā was an elaboration, but the version which Paul of Lagarde edited in the year I860, being incomplete, only has the quality of a poor epitome. Bar Bahlul cites very few words from the Syriac translation, to the extent that they are apparent, and to the extent that it is possible to distinguish, without specifying which of the above-mentioned books he used in his lexicon, as Immanuel Loew notes well, Aramaeische Pflanzennamen, 20.

In one place, I580:I6, an Arabic gloss said to come from كناب الفلاحة occurs. Nothing of this work is known. A Book of Agriculture, كتاب الفلاحة, is attributed to Hunayn by Ibn Abī Uṣaybica (ed. A. Mueller, 20o, I4). 


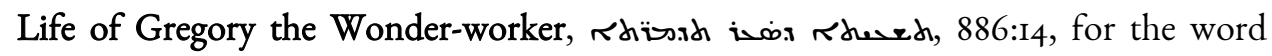
Rhw; cf. Bedjan, Acta mart. VI, 83.

Gregory of Nazianzus the Theologian; Gregory of Nyssa. "The Theologian” is cited several times in the lexicon: 169:2, 259:3 and II (Carmina iambica, cf. the edition of Bollig and Gismondi), 283:3, 485:14, I430:2, I824:17, 2045:ult, “The Nyssene” himself: II:I7, I67:19, I80:I3, 237:II, 243:2, 244:9, 286:17, 292:22, 963:4, I387:8, 1639:3, 2037, note 9; often "Gregory," without anything added to the name: 84:I0, 86:I,96:6, I26:3, I54:8, I60:ult, I80:22, I87:16, I89:23, I90:7, 192:14, I93:13, 204:I4, 240:22, 265:17, 270:8, 273:13, 279:20, 282:15, 284:13, 295:23, 298:I0, etc.; in addition, 1922:13, 1957:12, 1971:7, 2036:19, 2037:I5. In these places it seems the Nyssene is intended, whom Bar Bahlul expressly mentions in his preface.

The Hexameron, which was published under the name of the Nyssene, seems to have furnished many glosses for the lexicon, cf. P. S., Thes. syriacus, 266 (under мarfir). Glosses on geographical and Biblical names may have been excerpted from this work and from the Nyssene's commentaries on the Bible, 84:IO, 86:I, I54:8, 180:13, I80:22, I87:16, 244:9, 295:23 (cf. 292:22). The work on Theology was much used and commented upon in its Syriac translation by the Syrians, 'Nestorians' as well as 'Jacobites', thus it is not surprising that it is cited in the lexicon, cf. "On Theology" 96:6 (Homilies of Saint Basil), 222:3, 282:15, and 283:3.

Book of the Harrānenes, حسأس 168:25, 507:11, 1037:23, 1226:7. Parts of this book, demonstrably written as a work of poetry, provide conserved Greek fables. The Mesopotamian city of Harrān, or Carrhae, preserved the practices of many ancient pagan religions, and the Syriac Christians held its inhabitants to be pagans, which in their language are called نiva. We hold unresolved whether the Book of the Harrānenes cited in Bar Bahlul's lexicon and the Book of the Pagans cited by Bar Hebraeus (Cuvres grammaticales, ed. Martin, I, 38, 1. 8) are one and the same work, cf. Fables of the Aramaeans, above. Another gloss of the lexicon, I420:2, refers to the "Prayers of the Harrānenes," which seems to be the same book, if one compares the text in Bar Hebraeus (Cuvres gramm., I, 38, 1. I8). This work seems to have been composed in (decasyllabic?) verse. Whether a gloss on the word $r_{5}$, which Bar Bahlul

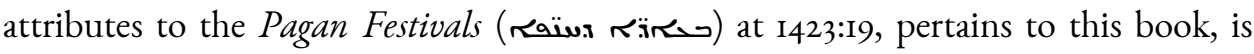
doubtful but possible.

The Heraclea (Version of the New Testament), reviw, 198:2, 4, and 7; 200:ult.; 258:8; 314: ult.; glosses added by a 'Jacobite' interpolator. 
Hexaplar (Syriac Version of the Old Testament), rua, passim.

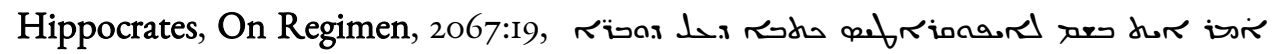

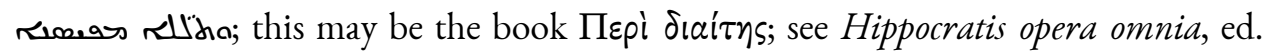
Gottlob Kühn, I, 625 and subsequent.

Hubayš al-A'sam, the much-celebrated physician, student of Hunayn and his son-inlaw, is cited a single time, II:I8:ذكر عنه حبيش الأعسم, "which (word) cited from Hubaysh

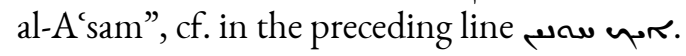

The Syriac translation of the works of Homer, which Theophilus of Edessa (t 785) prepared, is cited, I644:18, under the word ira, (which occurs) very frequently in this translation, as is said there.

Hunayn (\$ 873), iٔح, i. Bar Bahlul tells us in his Syriac preface, (see above, p. xi), that wherever the author of a definition is not indicated, it belongs to Rabban Hunayn. These words seem to refer to Hunayn's thesaurus and lexicon, cf. above, p. vii. ${ }^{32}$ Others of this author's works are cited after the fashion שתחה, namely: His Chronicon, 322:20, 684:17, 802:20, I781:19, and his translations of Greek works into Syriac and Arabic, to wit: I. On Foodstuffs, 583:3, 678:8, in Syriac and Arabic, as is clear from this gloss: اهحلحه..... فتّشت عنها فوجدت حنين قد ذكرها في نسخة من كَّابه في الأغذية بالدريانية وقابلت به عدّة نسخ

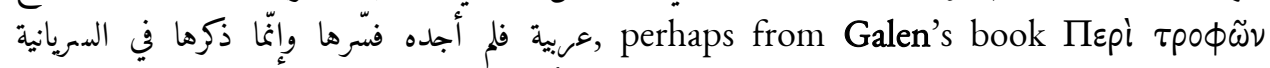

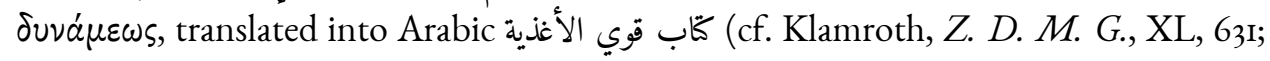
2). 2. His Syriac translation of Dioscorides. "In all, as Bar Bahlul informs us," as Immanuel Loew says, 33 "the important fragments of the Syriac version of Dioscorides prepared by Hunayn are very numerous, and many of these are introduced with the words translation of Dioscorides. ${ }^{34}$ Moreover, glosses are included which were taken from Hunayn's lexicon, 35 although selections from a translation may have sufficed." He

\footnotetext{
${ }^{32}$ The full title of Hunayn's lexicon may be seen written in full at column 667, line Io. Glosses excerpted from his book of ambiguous words are inserted with the words pi in $\propto$, for example at col. 1966:ult; 1967:I.

33 Aramaeische Pflanzennamen, 13.

${ }^{34}$ See the various drugs made from wine introduced with the words pi inor, columns 71-75.

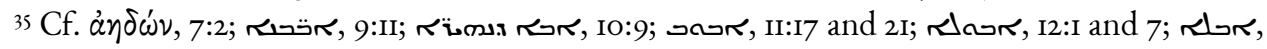

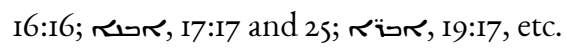


adds afterwards (p. Is): "Bar Bahlul, or whoever undertook to excerpt the glosses, provided such excerpts as were most correct; in truth, very few mistakes are to be found in the text. When (a gloss of) Gabriel's is to be corrected, and (a gloss of) Hunayn's is to be accepted (in its place), Bar Bahlul uses the word صحّة "he corrected it," as in all glosses that combine two sources.

"To Hunayn is owed the preservation of a great number of Greek words; when he translated these, it is done with circumspection, and we are able to confirm the smallest things; when he does not know (certain) Greek words, he confesses it openly;

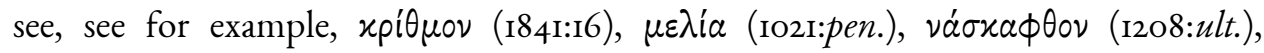

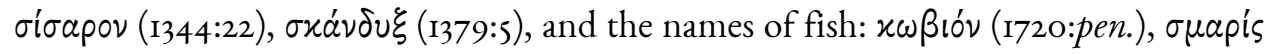
(1356:9).

"Which translation of Dioscorides Bar Bahlul excerpted has come into contention. Bar 'Ali often cites words in harmony with Hunayn, from whom he drew, and whom he calls Rabban, he having been his student. Bar 'Ali may have excerpted Hunayn, but our compendium of Bar 'Ali is too composite to admit consideration of the question. ${ }^{36}$ It seems likely that Bar Bahlul used Hunayn's translation of Dioscorides in the lexicon, and included his definitions (along with the word) حنين; see for example $\pi \alpha \dot{\alpha} \theta \varepsilon \circ \nu, \mathrm{I} 476: 14$. The Arabic commentary written by Hunayn is expressly cited, that is, (his) commentary on the Arabic version prepared by Stephen, which he revised. ${ }^{37}$ Hunayn is cited alongside Zachariah elsewhere, for example I468:II.

"Hunayn also examined the accuracy of the translations made by Sergius. But Sergius' own words, which Bar 'Ali and Bar Bahlul very often cite along with Hunayn in the lexicons, usually introduced with the words 2 , are in many points already confused with Hunayn's, cf. I521:I4, I846:15, I954:I.”

\footnotetext{
${ }^{36}$ Loew added this: "Why Bar Bahlul in some places wrote "Hunayn confirmed it" after Rabban may be understood in the following way: The one refers to Bar 'Ali, and the second to it

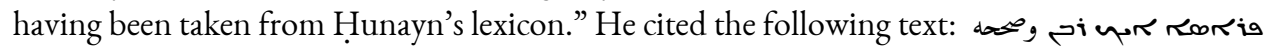

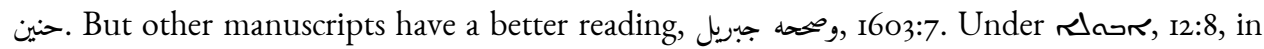
place of in Bar Bahlul's lexicon save for once or twice in certain manuscripts.

37 With these words Loew alludes to a gloss on the word ảßpó $\tau o v o v$, which he reports as fol-

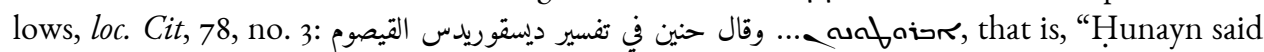

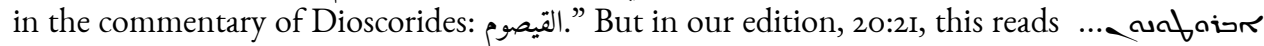
,وقال حنين تفسيره عن ديسقوريدس هو القيصوم that is, "Hunayn said, 'The interpretation of this (Ara-

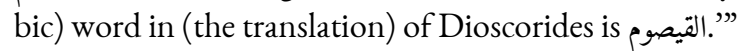


Hub, or Job. Under the name wạ a certain number of Syriac glosses on terms from the Old Testament are inserted in the lexicon. The manuscripts unanimously exhibit (the name) (aw in the following glosses: ffotor, 223:13 (Gen. xxxvii, 25, Hex.);

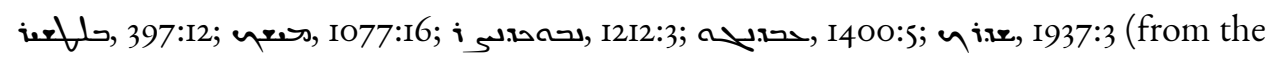
Book of Daniel); תمصنr, II 43:4. In other places the manuscripts do not agree, and var-

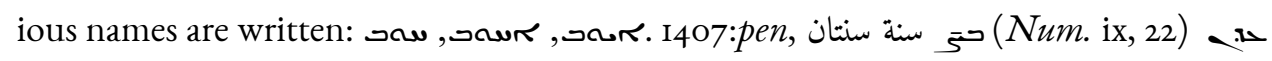

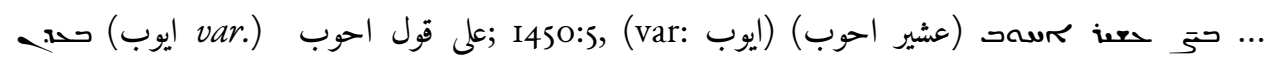

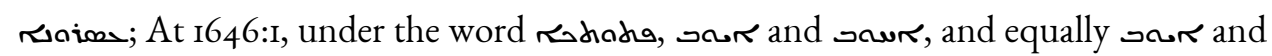
ملنh rard in Bar 'Ali, according to Payne Smith; 1792, note 22, under the word

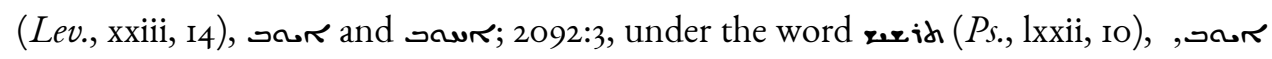
Jaw, All of these clearly cite the same book, which is very likely to be a book of interpretations of difficult words in the Old Testament; works of this type were not rare among the Syrians, cf. Hoffmann, Opuscula Nestoriana, 85 (and ibid., II6, where an interpretation of the names in the Book of Daniel attributed to saw occurs). Thus, two authors, one Hub and the other Job, should not be understood; , row would seem to be one and the same name; כaw and sowr have the appearance of no (other) Syriac names; very often sou is read for Job. Mari and Amr (ed. Gismondi, I, 55; II, 44) mention an Interpretation of Job, which coincided with the patriarchate of Jesuyabo in the year 58I. 'Abdišo', furthermore, cites in his catalogue a Job of Qatar (around the year 900), who commented on certain books of the Bible; cf. .

Ibn Sīnā, ابن سينا (manuscript H), ابن سينة (manuscript F), بنة (manuscripts SSs). We learn from some glosses that a (certain) physician named Ibn Sīnā was a contemporary of Bar Bahlul's, the citation of which is of interest: 90:I5, under öpos, وسألت عنه ابن سينا

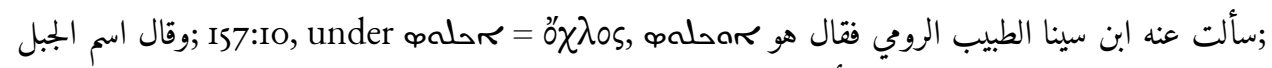

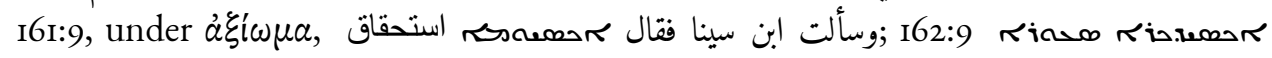

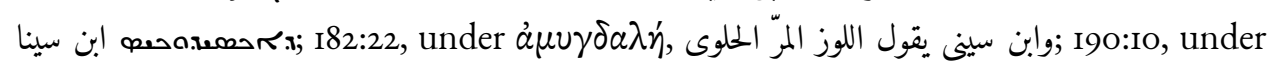

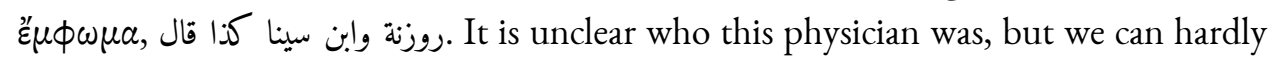
mention another than the illustrious Avicenna (ابن سينا (إل), who was born in the year 978 and died in the year 1036, and thus would seem to have lived after Bar Bahlul, if (the latter) in fact flourished around the year 963; yet it is not unthinkable that Bar Bahlul would have lived to the beginning of the IIth century. The epithet "Greek physician" (الطبيب الرومي) I57:IO) is surprising, since it is known that Avicenna migrated from the Orient; this perhaps could refer to Avicenna's being imbued with Greek learning. Howsoever it is, it is clear that Payne Smith is not to be followed (on this matter), who 
wrote, at column 6os in his catalogue to the manuscripts held in the Bodleian library, "Bar Bahlul worked very carefully in his lexicon, and frequently mentions that he consulted Elias of Nisibis for difficult texts, (writing) سألت ابن سينى.” It is true that Elias of Nisibis was commonly called "Ibn Sīnā," as Amr said (ed. Gismondi, pars altera, 99, line 3): مار إيليا مطران نصيبين المعروف بابن السنى, but he was not a physician, and lived much later than Bar Bahlul, dying after the year Ioso.

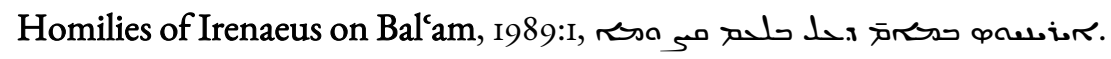

Isaiah the Ascetic, r.tew Rever, 724:13. For the Syriac works of Isaiah, who lived as an ascetic in the Egyptian desert of Scete, see Wright, Catal., General Index, under the entry Isaiah of Scete.

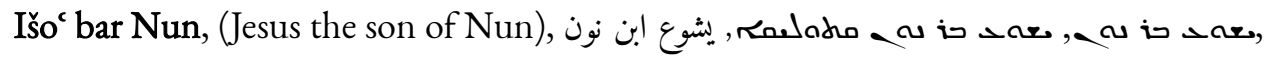
who was made patriarch of the 'Nestorians' in the year 823 and died four years later: 52:1, 60:4, 79:12, 106:27, 123:6 and I0, 216:5, 416:3, 551:2, 650:22, 652:19, 715:17, I193:22, II94:2, I768:19, I840:4, 2078:3. Išo ' bar Nun wrote many works (see Assemani, B. O., III, i, I65), and it is difficult to say from which book Bar Bahlul took the glosses cited under his name. Nevertheless, the citations, 551:2, 652:19, II93:22, II94:2, I768:19, I840:4, 2078:3, seem to pertain to a glossary of synonyms and doubtful words, such as that mentioned by Bar Hebraeus (Cuvres grammat., ed. Martin, II, 77). The Greek words, 52:1, 79:12, 106:27, 123:6 and 10, 216:5, may have been taken from this book, whereas the word aena if.am, at 650:22 perhaps comes from his Biblical Questions (cf. Payne Smith, Thes. syr. I032, for this word), to which the glosses 60:4 and 715:17 may also refer; the gloss 416:3 may cite the Biblical book of Joshua.

Išo'bokht (Jesubocht), שحصג, 287:7, 420:21, 875:6, 878:19, 900:ult., 1394:3, I462:21, 1676:9, I726:16, I761:10, I777:2. Which author is cited in these places is not known. A Jesubocht is mentioned in 'Abdišo's catalogue (see Assemani's Bibliothecam orient., III, i, 194) as metropolitan of Persia, whose book on the Universe is said to be composed of ecclesiastical resolutions and works of prophecy. But in Bar Bahlul's lexicon, it is clear that the glosses under the name of Jesubocht refer to a physician, as they concern names of plants and vessels of medical use, 287:7, 420:2I. Jesubocht may be the same as the name Bokhtišo', just as the monk Zechajesu is sometimes called Jesuzecha. In Baghdad, as we have said above, the celebrated (Bokhtišo') family of physicians once flourished, two of whom the name Bokhtišo', cited without any cognomen, may designate, to wit, Bokhtišo' the son of George and Bokhtišo' the son of Gabriel, both of whom wrote books of medicine. Bar Bahlul tells us that a book of 
expositions of causes, written meritis or merita 5 , was published by Jesubocht, 1679:9.

Išo of Merv, also called Zachariah of Merv (Bar Bahlul in his preface calls him riv rinis), author of a Syriac lexicon, as we said above, p. viii, out of which Bar Bahlul excerpted many glosses, and whom (Bar Bahlul) designated in the following ways: احiٔم, احiَ, Tis This name occurs in 600 citations, but the name کrais so is written only a single time, 835:I4.

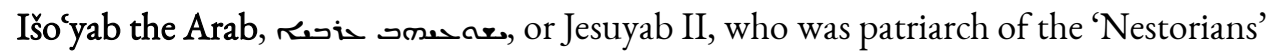
during the years 628-644. His commentary on the Psalms, which 'Abdišo' mentions in his catalogue (Assemani, B. O., III, part i, I05), on Psalm xvi, 6, is cited, 7II:26, $832: 4-5$.

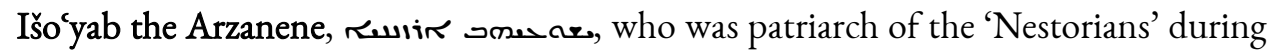
the years 58I-595, is cited on the word $\sim \infty 1 \sim$, 167:2I. For his works see the catalogue of 'Abdišo', in Assemani, B. O., III, part i, Io8.

Jacob of Edessa ( 708 ). The following works of his are cited in the lexicon: I. Hexaemeron, under the name rearas "the Blessed Commentator," 779:25, on the

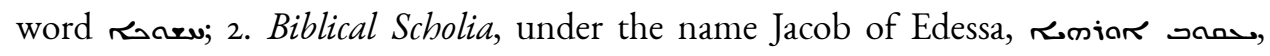
II6:pen., on Job; 907:9, on the item of vocabulary حaר; عרטה (Job, xxxix, I3); and 957:ult., on Luke the Evangelist.

Jacob the Presbyter. He is cited for the item 874:21:

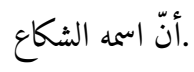

Jacob of Sarug ( $\$ 2 \mathrm{I}$ ). Three places from his metrical homilies under the name of Saint Jacob the Doctor, rials are cited in the lexicon: I. On Moses, I044:pen.; 2. From the sermon on the Flood, 1327, note 5, under the word rhive; 3. From his metrical oratory on death, 1865:3, under the word rusi, which oratory seems to differ from the sermon on death edited by Bedjan, Acta mart., V, 615, and VI, 674.

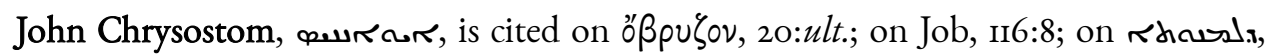
577:pen.

حكى ذلك : John, son of Henanišoc. This name occurs in the lexicon a single time, 1993:13 عن يوحنّا بن حننيشوع wich gloss seems to have been added after the composition of the lexicon, as it does not occur in some manuscripts; in other manuscripts the name بخن is written in place of حشوع ن ينيشوع; thus nothing certain can be said about this author. 


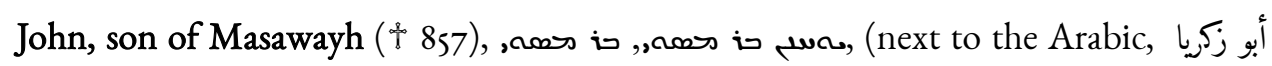
(يحيى بن ماسويه . A famous physician, he taught in Baghdad and had Hunayn among his students; he composed many works on the art of medicine in Syriac and Arabic and translated Greek books. Under his name Bar Bahlul cited not a few glosses in Syriac, I04:26, 258:16, 394:17, 638:13, 878:3, I495:13, I854:6, etc.

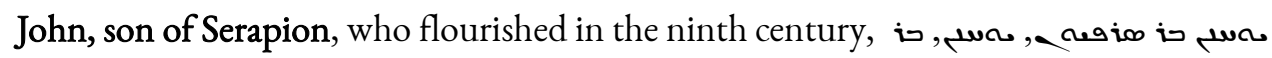
مأََ, يوحنّا بن سرافيون, ابن سرافيون Born the son of the great doctor Serapion, who came originally from the province of Bēt Garmay, he became a physician himself. He wrote in Syriac a large medical compendium in twelve books, and a smaller abridgement in seven books. Bar Bahlul seems to have cited the abridgement, which was widely used by physicians. He cited under the name of Bar Serapion many weighty Greek, Syriac, and Persian words relating to medicine, for example, II:22, 159:22, 209:24, 245:12, 265:15, 512:5, 514:21, 517:5 and 19, 518:ult., 525:8, 557:7, 579:21, 673:19, 677:22, 1377:6, I807:I8, I815:2, I847:7, I876:13, I884:14, I995:18, 2013:16, 2085, note 3 , and others of different types: II:22, I389:I4, I880:I5, 2024:I5, etc.

This brief compendium is said to have been translated into Arabic by Bar Bahlul and others, see above, p. x.

Job, see under Hub.

Jonah of Jordan,

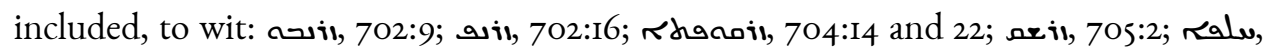
755:3. In the gloss at 705:2, the epithet, is is accorded him; it thus seems that this Jonah was a man of high eminence in the clerisy. In another place, 502:2, it reads: ; im mar, that is, masm, which occurs in the Book of Jonah, means "he vomited him out of his mouth." This may mean the book of the prophet Jonah, II, II, where the Pešițtā version shows the word mfla.

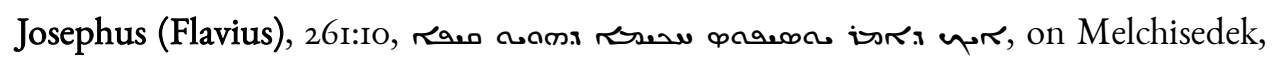

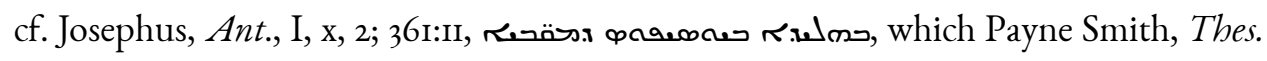
syr., col. 472 line 6, understood to mean that Josephus wrote the first book of Maccabees, but Bar Bahlul here may allude to (Josephus') book De martyrio septem fratrum Maccabaeorum; I779:II, معar. For the confusion of Josephus with the High Priest Caiphas, see: The Book of the Bee, ed. Budge, I06:7; Chronique de Michel le Syrien, ed. Chabot, text: 94, translation: I, I54; Bar Hebraeus, Chron. syr., ed. Bruns, 54:I2; ed. Bedjan, 5o:I; Assemani, B. O., II, I65; Cureton, Ancient Syriac Documents, I7I, note to page $3 \mathrm{I}$. 


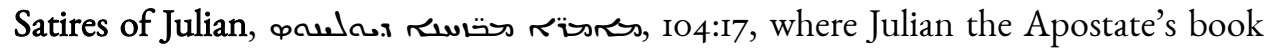
entitled Caesares appears to be cited, to which Michael the Syrian alluded in these

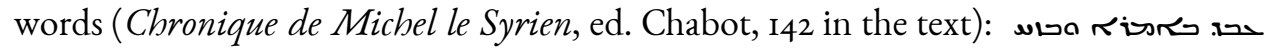

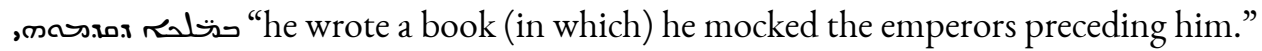

Julius the Roman, on Job, II6:7

Kalilag and Damnag. The Syriac and Arabic title of a book of fables, the Syriac version of which was edited by Bickell (Das Buch von Kalilag und Damnag, Leipzig, I876), cited under the letter in the following way: I789:II, مل 1794:4,

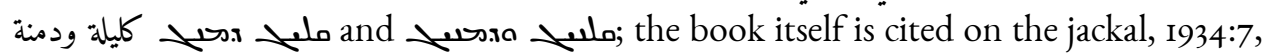
ع حلد ابن أوى من قليلج ودمنج

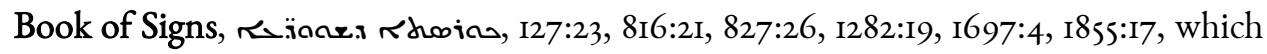
seems to have been a book of natural philosophy.

Book of Paradise; Book of the Persians. We have said a little in the preface to the first fascicule on this book, which the occidental manuscripts of the lexicon call The Book

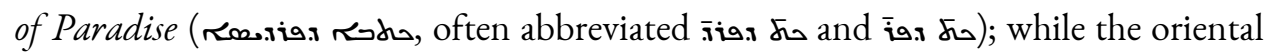
manuscripts rarely have that title, but often give the name Book of the Persians ( حas

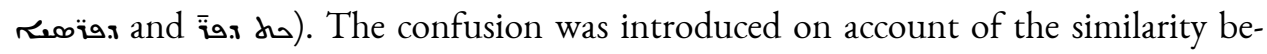
tween the abbreviation written (حָ surprising, given that it is a very famous work and often used as a reference (more than seventy times under the letter ālap alone).

It is clear that in some of these places glosses from the Lausiac Histories of Palladius, or Paradise of the Fathers, are excerpted. Several Syriac translations of this history were written, of which most widely used was the compilation collected by the monk 'Enanišo' in the seventh century and published in modern times by Patre Bedjan. The following glosses pertain to this (work): “’ ßía, 49:25, 50:I; نं

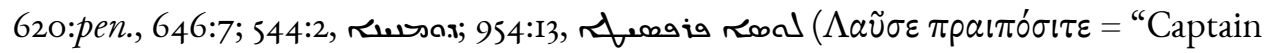
Lausus," for whom Palladius composed his history), and others which may be collected from Bedjan's edition. Furthermore, it is certain that Bar Bahlul used another work, whose title is given in very diverse ways. Certain Persian words at one time were insert-

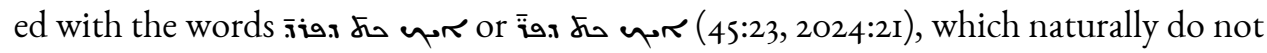
occur in Palladius' history. Each of the sources seem to be indicated under the word

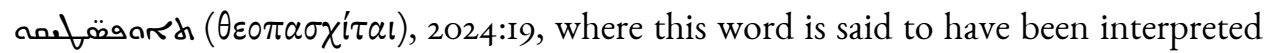

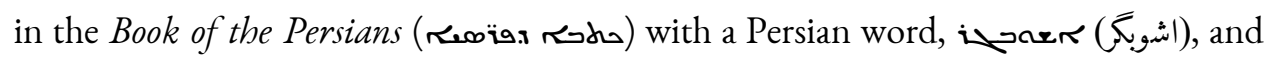
in the Book of Paradise with a Syriac phrase, דنur. Both books are cited in 


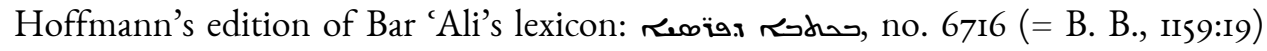

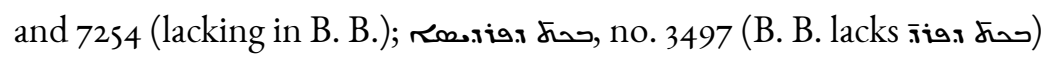

It is thus our belief that Bar Bahlul extracted glosses from both of these books, and that later scribes seem to have confused their titles. One was the Lausiac Histories, and the other the Book of Persians (perhaps a lexicon), most of the glosses of which in time came to be cited in this way. Under the letter alap alone 45 Greek words and 25 Syriac words are found noted after this fashion.

Massịh, مسيح. This cognomen is a designation of a Damascene physician, Abū alHassan, cf. Kitāb al-Fibrist, p. 297; but of him very little is known. It may be that in أبو السهل عيسى بن Bar Bahlul's lexicon it signifies Avicenna's teacher, whose full name was يحيى المسيح الجرجاني. Al-Massịịi died in the year Iooo, at the age of 40; he thus was a contemporary of Bar Bahlul's, who seems to have known of his student Avicenna (see Ibn Sīnā, above). Al-Massīhī wrote many works on medicine and physics in Arabic, the most notable of which is a compendium of the whole art of medicine, the Book of One Hundred Chapters. Under the name مسيح in the lexicon glosses are included which transcribe Greek words and usually provide explanations (of them), for example: 32:I; I73:I5; 204:ult.; 233:I4; 262:II; 863-865 (names of stones); I074:I7; 2029:II; 208I:5; rare Arabic and Persian words, for example: 229:6; I645:I; I859:6; 1916:I0. There is little likelihood that a Damascene physician would have been familiar with Persian medical vocabulary.

Methodius, متديّ" book Revelation to Methodius in Prison; see The Book of the Bee, ed. Budge, chapters lii-liv; Assemani, B. O., III, part i, 53; Migne, Patr.gr., vol. XVIII.

\section{The Mervene, see Išo of Merv.}

Michael, ميخايل, 794:ult:; under the word the taken from the Pešiṭtā version of the Old Testament. Michael himself, who was known by the cognomen "Interpreter of the Bible," seems to have lived around the year 9oo; he wrote (a book) of questions on the Holy Scriptures divided into three volumes. Cf. Assemani, B. O., III, part i, I47; The Book of the Bee, ed. Budge, chapter lvii; G. Hoffmann, Opuscula nestor., p. xxi.

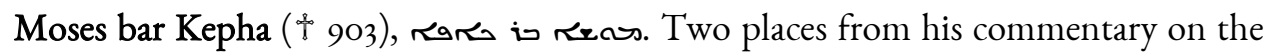
New Testament are cited: 500:2I, on the word (Matthew xix, 24), and 957:14, on Luke the evangelist.

Moses ibn Hunayn, موسى, موسى ابن حنين. This author is cited for a few Arabic glosses in 
the lexicon, I92:2I, 532:3; it is not clear from which work they were taken.

The Nativity of Our Lord Jesus Christ $\left(x^{\prime} \theta, \sigma \mu \alpha\right)$, 34I:I, on the word $د_{5}$ odir. This gloss seems to have been selected from the book of the 'Jacobite' Syriac liturgy, and is omitted in the 'Nestorian' manuscripts.

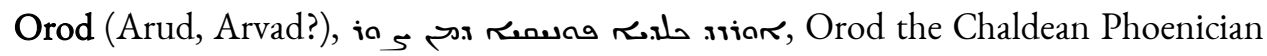
of Tyre, II6:Is and 23, on Job; cf. Payne Smith, Catal. cod. syr. Bibliothecae Bodleianae, 4, את, which P. S. translated Arvad bistoricus ("Arvad the Historian”); Chronique de Michel le Syrien, ed. Chabot, text I2, translation 24. אזin ralso B. H., Chron. syr., ed. Bruns, ı; ed. Bedjan, ı.

Paul of Aegina. The Arabic version of Paul of Aegina's compendium, ${ }^{38}$ which treats plants and materia medica, كاش فولوس (277:15; 1993:I3), is often referred to in Bar Bahlul's lexicon in the following ways: 9 a a

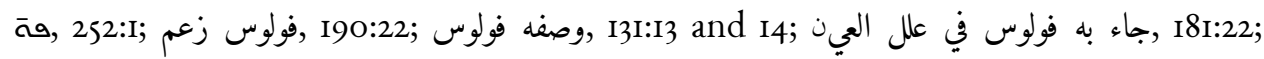
I84:I9, etc. For the compendious translation of the works of Dioscorides, Galen, and Paul that Gabriel seems to have compiled for use, see Gabriel, above. An Arabic commentary on Paul's compendium is not rarely cited: مفسّر فولوس , 789:8, IO22:4, I089:21,

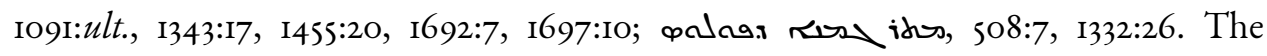
words صاحب كناب فولوس, 1661:19; 731:19 very likely indicate a note written in the margin of a manuscript by its owner. All of the glosses are in Arabic; $\bar{a}$ in col.

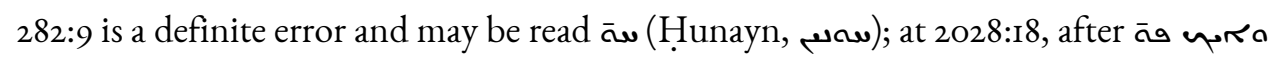
add التين and the following period from note 24.

Paul the son of 'Anqa, the Edessene, rmior war who is said to be the inventor of the Estrangelo script under the word N vifor, 226:I (where the phrase is

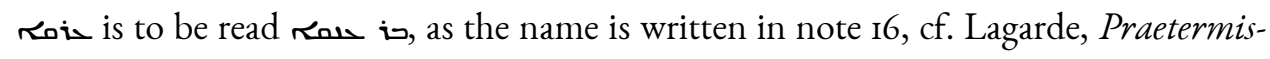
sorum libri duo, 96, line 3). It does not seem that this Paul is the same as Paul the Edessene, who translated Greek books into Syriac around the year 624 .

Pethion, فثيون, 1373:9; 1987:9; Arabic glosses on the names of gems. This may be the same as Pethion, the author of the history of the church, whom Elias of Nisibus mentioned and who lived and died in the eighth century.

${ }^{38}$ Bar Hebraeus, in his Libro Chronicorum arabico (ed. Pocockius, II4-II5; ed. Salhani, I76), wrote: "His (Paul of Aegina's) work is on medicine, and is divided into nine parts, which Hunayn the son of Isaac translated.” 


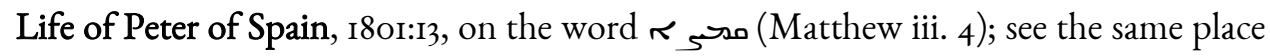
cited in Petrus der Iberer, ed. R. Raabe, $125-126$.

Physiologus. Three Syriac recensions of the Physiologus or the History of Animals have been discovered up to this time: The first in a Vatican manuscript, which Tychsen edited, the second in a Leiden manuscript, published by Land in Anecdotis syriacis, vol. IV, and a third in a London manuscript, which Ahrens submitted to the judgment of the public. The third recension does not deal solely with animals, but treats trees, stones, and geography, many parts of which Bar Bahlul took and cited verbatim, for example: 96:20 = Abrens, 49; 175:10 = Abr., 21-22; 262:15 = Ahr., 29; 692:23 = Abr., 36; 1006:16-23 = Abr., 66; 1322:15 = Abr., 39; 1324:19 = Abr., 49-50; 1348:1 $=A b r ., 59 ;$ I353:12 $=A h r ., 37 ;$ 1353:ult. $=A h r ., 50 ; 142 \mathrm{I}: 1 \mathrm{I}=A h r ., 42 ; 1677: 14=$ Abr., 34; 1690:19 = Abr., 53; 1747:I = Abr., 3I-32; 1758:pen. $=$ Abr., 25; 2044:18 = Ahr., 42-43. These are excerpted with no indication of their source, and the recension itself was recorded under the name of Aristotle and not that of the Physiologus, cf. 892:I: وجدت في كناب الحيوان المنسوب إلى اريسطوطاليس , where the following Arabic gloss consists of a summary from this recension. Yet the name Physiologus does occur in two places: 1294:22, wa vallwhich treats the word $\sigma \eta \pi i$, which does not occur in

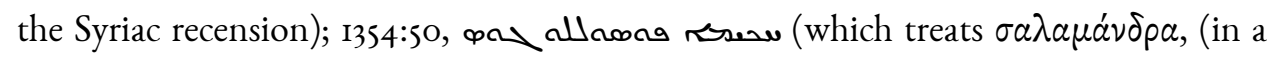
way) close to the Landian recension). In another place, 578:6, a gloss on the dolphin

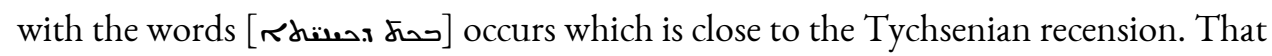
recension carries the title of shriologus). Bar Bahlul seems to have added these texts and others from an earlier compilation, cf. II5:7, 200:7, which is close to the Tychsenian recension (but occurs) with the words aiio ic; 127:7 (Land, chapter xvi; Ahrens, I5), etc. It is to be noted that the Physiologus is attributed to Basil the Great in the Landian recension; cf. Land, Scholia in Pbys. Leid., in volume IV Anecd. syriac., p. I33, and Basil the Great, above.

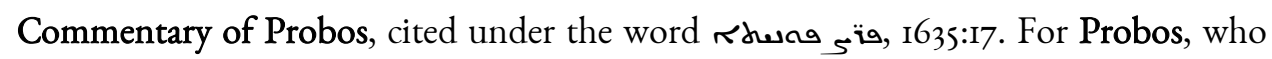
seems to have lived in the eighth century, and who wrote a commentary on Aristotle's

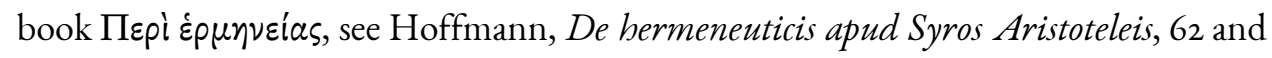
subsequent.

Al-Rāzì (t around the year 932), الرازي (in Arabic أبو بكر محد بن زكريا الرازي), the famous physician originally from the city of Rayy. The author of works of medicine of the highest regard, of which the Manșūri, Manșūr being said to be prefect of the city of

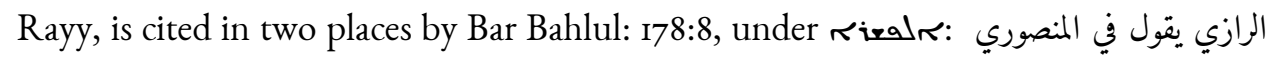


الفاشرا I645:I, under جاء به المنصوري الفاشرشتين :In each place he is cited for a species of living thing.

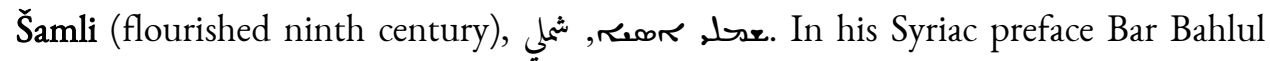
mentions Šamli to have written following Hunayn, and in fact the lexicon reads: حكاه شملي عن حنين , שsل, for example, I88:ult., and Under the name Šamli Greek words with Syriac and Arabic glosses are included: 22:16; 32:I; 47:22; 76:5; 89:19; I47:8; I77:I6; I82:7; I83:6 and II; I84:I3; I85:II; I88:13, I8, 22, and ult.; 193:II; 233:I4; 237:I; 243:IO; 247:16; 267:II; 271:9, 20, 23, and 27; 273:3; 275:13; 277:14; 298:20; etc. It is not clear from which work this vocabulary was excerpted. A translation of book $\Lambda$ of Aristotle's Metaphysics and a translation of a Book of the Humors, كناب الكيموس are attributed to Šamli (see Kitāb al-Fibrist, 251, 1.30; 290, 1. 25; Z. D. M. G., XL, 632).

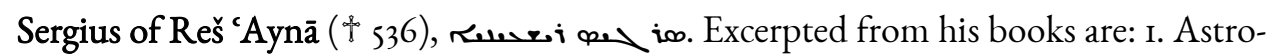

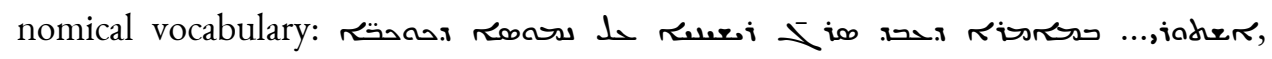
312:23-24 (cf. Sachau, Inedita syriaca, IOI and subsequent; Immanuel Loew, Aramaeische Pflanzennamen, 2I); 2. Names of plants and medicines: حivor under

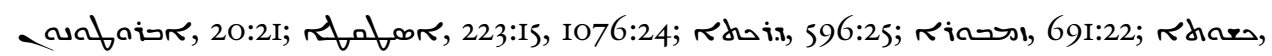

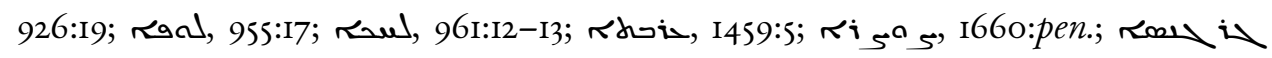

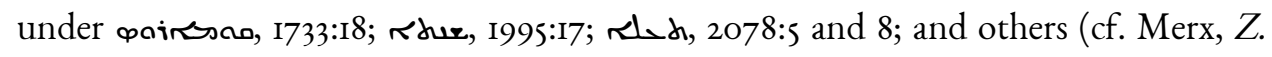
D. M. G., XXXIX, 237 and subsequent; Sachau, Inedita syr., 88 and subsequent; Imm. Loew, loc. cit., 20); 3. Ambiguous vocabulary and synonyms: salor, 62:ult.;

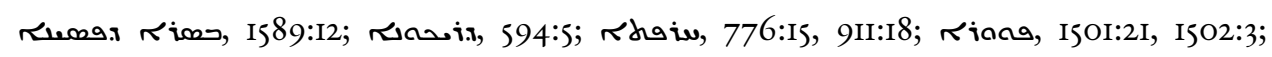

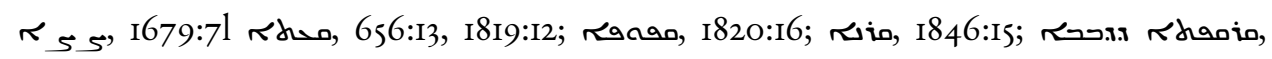

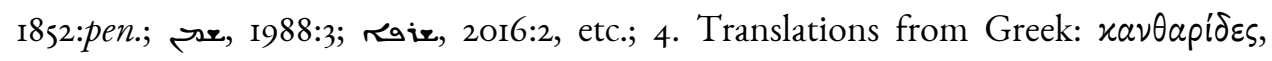

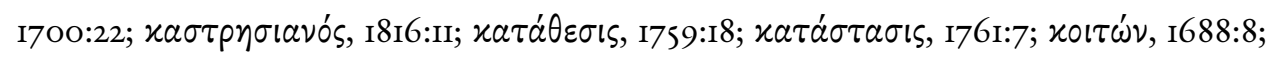

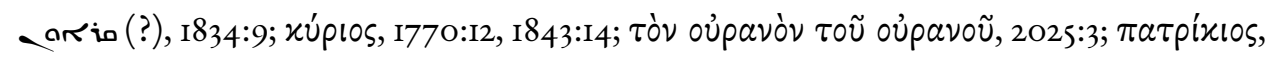

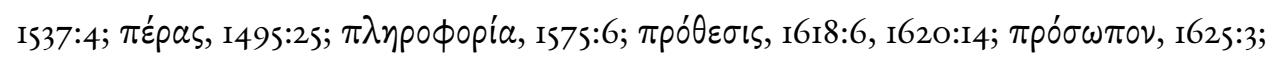

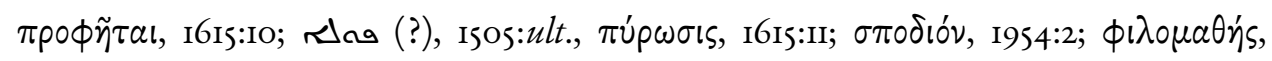

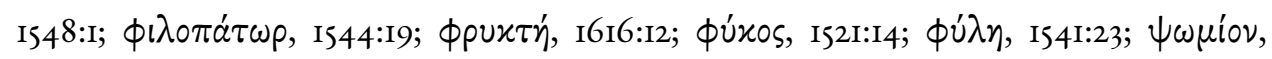
I54I:I3; $\phi \tilde{\omega} \varsigma$, I54I:6, etc. It is likely that Bar Bahlul took Sergius' glosses from Hunayn's lexicons (Imm. Loew, Aram. Pfl., I8). Cf. Hunayn, above. For the Syriac translation of the Geoponica which is referred to several times in the lexicon, very likely composed by Sergius, see Syriac Geoponica, above.

Simeon of Taybuta, mbiarb. nove, noted among the Syriac physicians (cf. B. H., Chron. eccl., II, I39; Chron. syr., ed. Bruns and Kirsch, 62; ed. Bedjan, 57), he flourished 
and died in the seventh century. 'Abdišo' mentions his book on medicine in his catalogue, see Assemani, B. O., III, part i, I8I. Bar Bahlul drew upon this book for a few glosses, 36:25; 83:24; 463:12; 1168:3; 2013:22.

Sinān ibn Thābit († 943), أبو سعيد سنان بن ثابت, بن قرة, originally of Carrhae (Harrān), he converted from the Sabian religion to the faith of Muhammad, and was physician to the caliphs Muqtadir, Kāhir, and Radị. The following gloss of Sinān's occurs in Bar Bahlul's lexicon 734:3: معic. We take this usage to mean that Sinān was a companion of Bar Bahlul's, if the gloss is sound; in some manuscripts the word لي is omitted.

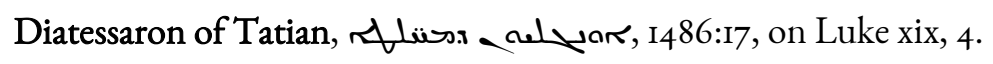

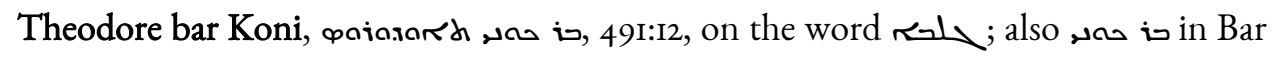
'Ali, ed. Hoffmann, number 288I. For this writer, who it seems lived at the beginning of the ninth century, cf. Pognon, Inscriptions mandaïtes des coupes de Khouabir, Append. II; Sachau, Verzeichniss der syr. Handschr., Vorrede, xiv, Nachschrift.

Theodore of Mopsuestia, whose Biblical commentary was translated into the Syriac language by Ibas and his students of Edessa during the fifth century, is cited three

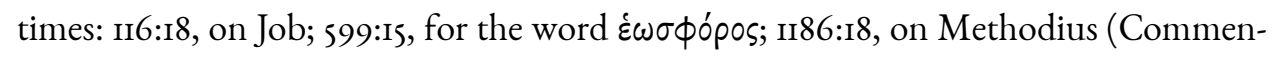
tary on the Psalter in five parts).

Theodosius of Edessa. nmiar soaxard. He flourished at the beginning of the ninth century, and was the brother of the patriarch Dionysius of Tellmahar; he translated an iambic poem and a sermon on the prophet Elias by Gregory the Nazianzene. In the lexicon, 92:pen., an interpretation of the word raior (U่pixós) is related under his name.

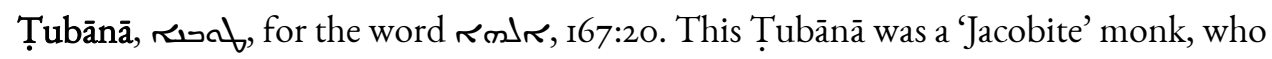
it seems worked a great deal in the Biblical tradition, or Massora, of the Syrians, cf. in the lexicon col. $1363,1.20$ and subsequent. He lived in the city of Reš 'Aynā at the beginning of the seventh century. It is notable that the relevant gloss does not occur in the 'Nestorian' manuscripts.

Yaḥyā ibn Ḥātim, see Bar Ḥatim above.

Zachariah of Merv, see Išo' of Merv.

Zosimus, enseoor, common for chemical vocabulary. Zosimus is often cited among the chemists; cf. Berthelot, La chimie au moyen âge, t. II, 408, under the word Zosime. 
He may be intended at I089:pen, where the word pasea.

\section{ON THE ARAMAIC DiALECTS CITED IN THE LEXICON}

It is obvious that the popular dialects of Babylon would be especially well-known to the lexicographers, who resided in Baghdad; thus it is not surprising that these are often cited in the lexicons of Bar 'Ali and Bar Bahlul. Thus, it will be helpful to give an exposition of these at the beginning.

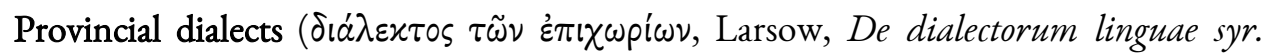

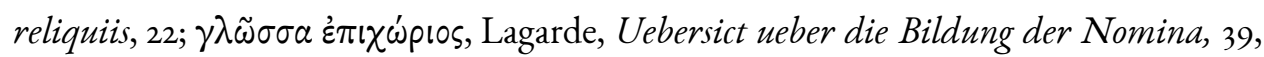
note 3, ritir rel, I88:10, 228:3, 438:4, 507:20, 575:10; 875:5, 2030:13, 2077:6. This seems to refer to the Aramaic speech of the people of southern Babylon and Arabic Iraq, cf. 507:20, revir ar ridir nel "the provincial language or Arabic."

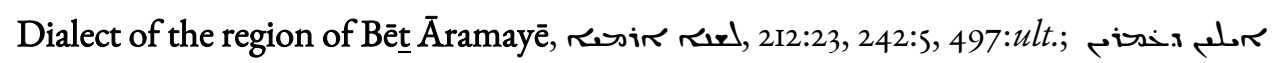

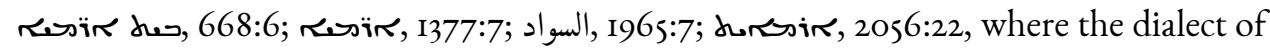
Mesena [الميسان] and now called by the Arabs Sawād al-Küfa (سواد الكوفة), see Noeldeke, Z. D. M. G., $\mathrm{XXV}, \mathrm{II} 4-\mathrm{II} 5$.

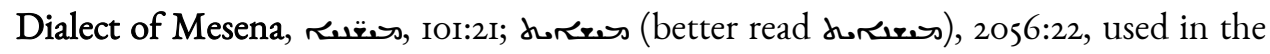
region of Mesena, which is called by the Arabs Sawād al-Bașrā; cf. Noeldeke, cited (in the previous entry).

Dialect of Qatar (on the Arab shore of the Persian Gulf), 几 ఒ

Dialect of Mațarta (Arabic مطيرة, near Samarra?), Rhibsid, 1752:12.

Dialect of Tagrīt or Țirhān, which was most familiar to the ears of Bar Bahlul, who indeed hailed from the province of Tirhān (also Ṭinhān), as we said above on p. x. The usages of this dialect are often related in the (following) ways: , mitb, a mb ad

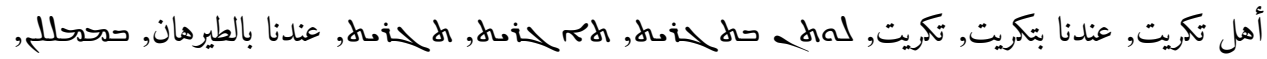
- mit sib; out of many (examples), we give: I06:15, I92:2, 45I:I, 498:I4, 503:7, 514:24, 536:9, 733:I0, 751:5, 768:18, 820:I2, I392:II, I745:I2, I784:19, I852:3, I855:pen., I891:7, I906:I8, I916:I8, I937:8, 1943:7, 1997:7, 1999:II, 2048:6, 2075:8. The Arabs called this region Bārimma (بارمّمَ", in the mountain of Hemrīn, near Takrît), as is clear from the gloss 867:I7: عندنا ببارمّا

Dialect of the Higher Regions, اللغة العالية, ممiتسم إللد, I54:2I, 